\title{
Therapeutic itinerary of families of children with chronic diseases
}

\author{
I 1 Janis Marcondes Rodriguez, ${ }^{2}$ Luciana Palacio Fernandes Cabeça, \\ ${ }^{3}$ Luciana de Lione Melo I
}

Abstract: Objective: to understand the Therapeutic Itineraries of families of children with chronic diseases. Method: phenomenological study conducted at a university hospital, with ten families of children with chronic diseases who participated in a phenomenological interview with the guiding question - 'Tell me about the path you (and your family) traveled in search of health care for your child before arriving at this hospital'. Results: four thematic categories emerged: Walking in search of health care for their child - the beginning of the saga; Perceiving themselves as vulnerable in front of the Unified Health System; From the difficulty to get access to health care to unexpected help and Arriving at the reference service - from the relief of care to the perception of the existence of new problems. Discussion: some families were referred by bonds of friendship, transfer through zero vacancy and spontaneous demand in other health services. After the diagnosis and beginning of treatment, the family showed hope for a cure, reporting a sense of relief when they saw the child being cared for. Conclusion: it was evidenced that children with chronic diseases and their families experience a long process of seeking access to health care, mainly due to the need for referral to referral hospitals.

> Palavras-chave: family; access to health services; pediatric nursing.

\author{
${ }^{1}$ UNICAMP - University of \\ Campinas. Campinas-SP, Brazil \\ (janisr1796@gmail.com). \\ ORCID: 0000-0003-1918-4172 \\ ${ }^{2}$ UNICAMP - University of \\ Campinas. Campinas-SP, Brazil \\ (cabeclp@gmail.com). \\ ORCID: 0000-0001-9150-6135 \\ ${ }^{3}$ UNICAMP - University of \\ Campinas. Campinas-SP, Brazil \\ (lulione@unicamp.br). \\ ORCID: 0000-0002-6730-9075
}

Received on: 05/11/2019

Approved on: 22/07/2020

Revised on: 17/10/2021 


\section{Introduction}

The term Therapeutic Itinerary refers to the movement that individuals/groups carry out in order to preserve or recover health, including home care, religious practices and traditional health care, and decision making about health problems (RABELO; ALVES; SOUZA, 1999).

As of the 1980s, cultural issues began to be considered, since an individual's health choices are also influenced by the sociocultural context in which he or she is inserted. Therefore, beliefs about the causes of disease, experiences with symptoms, patient behavior, and choices about treatment, therapeutic practices and outcomes are associated with a particular culture, which influences human behaviors (CHELO et al., 2016). In addition to the sociocultural context, the support received and the use of formal and/or informal networks are also included (RABELO; ALVES; SOUZA, 1999; ALVES, 2015).

In developing countries, it is common to observe different practices in the search for solutions to health problems, because, although resources exist, few people have access to them. This is how self-medication is a frequent practice, using medicines from pharmacies, as well as herbs and other natural products, sold by street vendors, on the streets, without authorization, therefore, an informal and illegal sale. The choice of product is based on the beneficial effects or on experiences reported by other people (NDIAYE; SARLI, 2014).

As part of cultural tradition, there is a strong link between care and the female gender, due to the fact that this function is considered innate and natural to the female figure (SIQUEIRA; JESUS; CAMARGO, 2016). This statement, according to Elizabeth Badinter (1985) in her classic work "A conquered love: the myth of maternal love", should not be considered a universal law, but a role that is acquired, depending on the historical and cultural construction of the woman. However, studies show that mothers are considered the main caregivers of children with chronic diseases, protagonists in facing the demands of care, sometimes being the only caregivers (SALVADOR et al., 2015; COLESANTE et al., 2015; MARTINS et al., 2019).

Chronic disease is characterized by a slow and progressive course, long duration, with relapsing symptoms and the need for hospitalization at least once a year, and may be related to multiple causes. The worsening of the chronic disease can lead to disabilities affecting the activities of daily living. Treatment involves changes in lifestyle with ongoing care (BRASIL, 2013). 
With the increasing incidence of chronic non-communicable diseases and the consequent reduction of acute diseases in children and adolescents worldwide, there is a need to understand what it is like to live with a chronic disease and the family, social and financial changes imposed by this disease, since the condition affects the entire family nucleus (BRASIL, 2013; MOURA, 2013; FERNANDES et al., 2017).

Given the above, considering the impact of chronic disease in childhood and the possibility of the family experiencing a long process of seeking access to health, especially considering the geographical dimension of Brazil and the location of specialized services, usually in large urban centers, this study aimed to understand the therapeutic itineraries of families of children with chronic diseases.

\section{Method}

This is a qualitative study in the phenomenological mode, which aims to understand the human being, his perspectives and his world (PEREIRA, 2015), from the analysis of the structure of the situated phenomenon, having as methodological reference the guidelines of Martins and Bicudo (MARTINS; BICUDO, 2005).

It is fundamental that the researcher interrogates a certain phenomenon and not only finds a problem and wants to solve it through a cause and effect relationship (PEREIRA, 2015). Phenomenon is what shows itself in an act of intuition and perception. Therefore, it is not an object already given in the world, but one that shows itself to an individually contextualized subject that experiences it. Experience, for phenomenological research, is not only the experiences of an individual in the world, because experience has a less subjective content and density, referring to something that is sensorially perceived, and cannot be reduced to memories or feelings, because it is at the core of a person's constitution (BICUDO, 2011).

Thus, the aim was to understand the phenomenon, that is, the experiences that encompass the therapeutic itineraries of the families of children with chronic diseases from their experiences as unique individuals. Ten families of children with chronic diseases who were hospitalized participated in the study, eight mothers and two fathers. To ensure anonymity, the real names were replaced by fictional names of characters from feature films whose plot addressed healthillness issues, according to Chart 1 . Other names mentioned by the participants were also changed to common names. 
Chart 1. Study participants, 2019

\begin{tabular}{|c|c|c|c|c|}
\hline $\begin{array}{l}\text { Participant } \\
\text { Age }\end{array}$ & $\begin{array}{l}\text { Child } \\
\text { Age }\end{array}$ & Child diagnosis & $\begin{array}{c}\text { City of origin } \\
\text { Department of } \\
\text { Health Regulation }\end{array}$ & $\begin{array}{l}\text { Family trajectory in the Health } \\
\text { System }\end{array}$ \\
\hline $\begin{array}{c}\text { Isabel } \\
45 \text { years old }\end{array}$ & $\begin{array}{l}\text { Auggie } \\
11 \text { years } \\
\text { old }\end{array}$ & $\begin{array}{c}\text { Chronic Kidney } \\
\text { Failure } \\
\text { Hepatitis }\end{array}$ & $\begin{array}{c}\text { Indaiatuba - SP } \\
\text { DHR-VII }\end{array}$ & $\begin{array}{l}\text { Hospital for Secondary Health } \\
\text { Care (Indaiatuba-SP) } \rightarrow \text { via } \\
\text { CROSS - Specialized Care } \\
\text { Hospital (Campinas-SP) } \\
\rightarrow \text { via CROSS - University } \\
\text { Hospital (Campinas-SP) } \rightarrow \\
\text { Specialized Outpatient Care } \\
\text { at the University Hospital } \\
\text { (Campinas-SP) } \rightarrow \text { University } \\
\text { Hospital ER (Campinas-SP) } \rightarrow \\
\text { Specialized Outpatient Care } \\
\text { at the University Hospital } \\
\text { (Campinas-SP) }\end{array}$ \\
\hline $\begin{array}{c}\text { Luck } \\
36 \text { years old }\end{array}$ & $\begin{array}{l}\text { Ben } \\
4 \text { years } \\
\text { old }\end{array}$ & $\begin{array}{l}\text { Spinal Muscular } \\
\text { Atrophy }\end{array}$ & $\begin{array}{c}\text { Aguaí - SP } \\
\text { DHR-XIV } \rightarrow \text { DHR- } \\
\text { VII }\end{array}$ & $\begin{array}{l}\text { Hospital for Secondary Health } \\
\text { Care ER (Aguaí-SP) } \rightarrow \text { Hospital } \\
\text { for Secondary Health Care ER } \\
\text { (São João da Boa Vista - SP) } \\
\rightarrow \text { via CROSS Pediatric ICU } \\
\text { University Hospital (Campinas- } \\
\text { SP) } \rightarrow \text { Specialized Outpatient } \\
\text { Care at the University Hospital } \\
\text { (Campinas-SP) }\end{array}$ \\
\hline $\begin{array}{c}\text { Kate } \\
34 \text { years old }\end{array}$ & $\begin{array}{l}\text { Helen } \\
3 \text { years } \\
\text { old }\end{array}$ & $\begin{array}{l}\text { Severe Hearing } \\
\text { Loss }\end{array}$ & $\begin{array}{c}\text { Salto-SP } \\
\text { DHR-XVI } \rightarrow \\
\text { DHR-I } \rightarrow \text { DHR- } \\
\text { XVI } \rightarrow \\
\text { DHR -VII }\end{array}$ & $\begin{array}{l}\text { Maternity ward (Salto-SP) } \\
\rightarrow \text { via CROSS Neonatal } \\
\text { ICU(Santo André-SP) } \rightarrow \\
\text { Specialty Medical Clinic (Salto- } \\
\text { SP) } \rightarrow \text { NGO (Sorocaba-SP) } \rightarrow \\
\text { Specialized Outpatient Care } \\
\text { (Sorocaba-SP) } \rightarrow \text { Univeristy } \\
\text { Hospital (Campinas-SP) } \rightarrow \\
\text { Specialized Outpatient Care } \\
\text { at the University Hospital } \\
\text { (Campinas-SP) }\end{array}$ \\
\hline
\end{tabular}

to be continued... 


\begin{tabular}{|c|c|c|c|c|}
\hline $\begin{array}{c}\text { Participant } \\
\text { Age }\end{array}$ & $\begin{array}{l}\text { Child } \\
\text { Age }\end{array}$ & Child diagnosis & $\begin{array}{c}\text { City of origin } \\
\text { Department of } \\
\text { Health Regulation }\end{array}$ & $\begin{array}{c}\text { Family trajectory in the Health } \\
\text { System }\end{array}$ \\
\hline $\begin{array}{c}\text { Maria } \\
25 \text { years old }\end{array}$ & $\begin{array}{l}\text { Thomas } \\
2 \text { years } \\
\text { old }\end{array}$ & $\begin{array}{l}\text { Leigh Syndrome. } \\
\text { Extrapyramidal/ } \\
\text { Pyramidal } \\
\text { Epilepsy }\end{array}$ & $\begin{array}{c}\text { Arthur Nogueira- } \\
\text { SP } \\
\text { DHR-VII }\end{array}$ & $\begin{array}{l}\text { Primary Health Care (Arthur } \\
\text { Nogueira-SP) } \rightarrow \text { Specialty } \\
\text { Outpatient Clinic (Arthur } \\
\text { Nogueira-SP) } \rightarrow \text { Hospital for } \\
\text { Secondary Health Care ER } \\
\text { (Arthur Nogueira-SP) } \rightarrow \text { via } \\
\text { CROSS University Hospital } \\
\text { (Campinas-SP) } \rightarrow \text { Specialized } \\
\text { Outpatient Care (Arthur } \\
\text { Nogueira-SP) } \rightarrow \text { University } \\
\text { Hospital (Campinas-SP) } \rightarrow \\
\text { Specialized Outpatient Care } \\
\text { at the University Hospital } \\
\text { (Campinas-SP) }\end{array}$ \\
\hline $\begin{array}{c}\text { Frannie } \\
20 \text { years old }\end{array}$ & $\begin{array}{l}\text { Hazel } \\
4 \text { years } \\
\text { old }\end{array}$ & $\begin{array}{l}\text { Rheumatoid } \\
\text { Arthritis }\end{array}$ & $\begin{array}{c}\text { Conchal-SP } \\
\text { DHR -X } \rightarrow \text { DHR } \\
\text {-VII } \rightarrow \text { DHR-X } \rightarrow \\
\text { DHR -VII }\end{array}$ & $\begin{array}{l}\text { Specialty Outpatient Clinic } \\
\text { (Conchal-SP) } \rightarrow \text { Specialized } \\
\text { Outpatient Care at the } \\
\text { University Hospital (Campinas- } \\
\text { SP) } \rightarrow \text { Specialized Outpatient } \\
\text { Care (Conchal-SP) } \rightarrow \text { University } \\
\text { Hospital (Campinas-SP) }\end{array}$ \\
\hline $\begin{array}{c}\text { Emma } \\
35 \text { years old }\end{array}$ & $\begin{array}{l}\text { Pepper } \\
3 \text { months } \\
\text { old }\end{array}$ & $\begin{array}{l}\text { Atresia of the } \\
\text { Biliary Tract }\end{array}$ & $\begin{array}{c}\text { Jaguariúna-SP } \\
\text { DHR -VII } \rightarrow \text { DHR } \\
\text {-XIV } \rightarrow \text { DHR -VII }\end{array}$ & $\begin{array}{l}\text { Maternity ward (Jaguariúna-SP) } \\
\rightarrow \text { Specialty Outpatient Clinic } \\
\text { (Jaguariúna-SP) } \rightarrow \text { Specialty } \\
\text { Outpatient Clinic (São João } \\
\text { da Boa Vista-SP) } \rightarrow \text { Specialty } \\
\text { Outpatient Clinic (Jaguariúna- } \\
\text { SP) } \rightarrow \text { University Hospital ER } \\
\text { (Campinas-SP) } \rightarrow \text { University } \\
\text { Hospital (Campinas-SP) } \rightarrow \\
\text { Specialized Outpatient Care } \\
\text { at the University Hospital } \\
\text { (Campinas-SP) }\end{array}$ \\
\hline
\end{tabular}

to be continued... 


\begin{tabular}{|c|c|c|c|c|}
\hline $\begin{array}{c}\text { Participant } \\
\text { Age }\end{array}$ & $\begin{array}{l}\text { Child } \\
\text { Age }\end{array}$ & Child diagnosis & $\begin{array}{c}\text { City of origin } \\
\text { Department of } \\
\text { Health Regulation }\end{array}$ & $\begin{array}{c}\text { Family trajectory in the Health } \\
\text { System }\end{array}$ \\
\hline $\begin{array}{c}\text { Sara } \\
33 \text { years old }\end{array}$ & $\begin{array}{c}\text { Anna } \\
2 \text { months } \\
\text { old }\end{array}$ & $\begin{array}{l}\text { Ohtahara } \\
\text { Syndrome }\end{array}$ & $\begin{array}{l}\text { Hortolândia-SP } \\
\text { DHR -VII }\end{array}$ & $\begin{array}{l}\text { PS Hospital de Atenção } \\
\text { Secundária em Saúde } \\
\text { (Hortolândia-SP) } \rightarrow \text { via Vaga } \\
\text { Zero PS (Sumaré-SP) } \rightarrow \text { UTI } \\
\text { Pediátrica (Sumaré-SP) } \rightarrow \text { via } \\
\text { CROSS Hospital Universitário } \\
\text { (Campinas-SP) }\end{array}$ \\
\hline $\begin{array}{c}\text { Michaela } \\
32 \text { years old }\end{array}$ & $\begin{array}{l}\text { Lorenzo } \\
11 \text { years } \\
\text { old }\end{array}$ & $\begin{array}{c}\text { Heart } \\
\text { Transplantation } \\
\text { PO }\end{array}$ & $\begin{array}{c}\text { Pindamonhangaba- } \\
\text { SP } \\
\text { DHR -XVII } \rightarrow \text { DHR } \\
- \text { I } \rightarrow \text { DHR -VII }\end{array}$ & $\begin{array}{l}\text { Specialized Outpatient } \\
\text { Care (Pindamonhangaba- } \\
\text { SP) } \rightarrow \text { Specialized Care } \\
\text { Hospital (São Paulo - SP) } \rightarrow \\
\text { Specialty Outpatient Clinic } \\
\text { (Pindamonhangaba-SP) } \\
\rightarrow \text { Specialized Outpatient } \\
\text { Care (Taubaté-SP) } \rightarrow \\
\text { Specialized Outpatient Care } \\
\text { (Sáo José dos Campos-SP) } \\
\rightarrow \text { Specialty Outpatient } \\
\text { Clinic (Pindamonhangaba- } \\
\text { SP) } \rightarrow \text { University Hospital } \\
\text { (Campinas-SP) }\end{array}$ \\
\hline $\begin{array}{c}\text { Saw } \\
26 \text { years old }\end{array}$ & $\begin{array}{l}\text { Lucy } \\
1 \text { year old }\end{array}$ & $\begin{array}{l}\text { Microcephaly } \\
\text { Congenital } \\
\text { cataract } \\
\text { Gastroesophageal } \\
\text { reflux }\end{array}$ & $\begin{array}{c}\text { Varginha-MG } \\
\text { SRS-Varginha/MG } \\
\rightarrow \text { DHR-I } \rightarrow \text { DHR- } \\
\text { VII } \rightarrow \text { DHR-I } \rightarrow \\
\text { SRS-Brasília/DF } \rightarrow \\
\text { DHR-VII }\end{array}$ & $\begin{array}{l}\text { Specialty Outpatient Clinic } \\
\text { (Varginha-MG) } \rightarrow \text { Specialized } \\
\text { Outpatient Care (Varginha- } \\
\text { MG) } \rightarrow \text { Specialty Outpatient } \\
\text { Clinic (Sáo Paulo-SP) } \rightarrow \\
\text { Specialized Outpatient Care } \\
\text { at the University Hospital } \\
\text { (Campinas-SP) } \rightarrow \text { Specialty } \\
\text { Outpatient Clinic (Brasília - } \\
\text { DF) } \rightarrow \text { Specialized Outpatient } \\
\text { Care at the University Hospital } \\
\text { (Campinas-SP) } \rightarrow \text { University } \\
\text { Hospital (Campinas-SP) }\end{array}$ \\
\hline
\end{tabular}

to be continued... 


\begin{tabular}{|c|c|c|c|c|}
\hline $\begin{array}{l}\text { Participant } \\
\text { Age }\end{array}$ & $\begin{array}{l}\text { Child } \\
\text { Age }\end{array}$ & Child diagnosis & $\begin{array}{c}\text { City of origin } \\
\text { Department of } \\
\text { Health Regulation }\end{array}$ & $\begin{array}{l}\text { Family trajectory in the Health } \\
\text { System }\end{array}$ \\
\hline $\begin{array}{l}\text { Christy } \\
30 \text { years old }\end{array}$ & $\begin{array}{l}\text { Abby } \\
2 \text { years } \\
\text { old }\end{array}$ & Crohn's Disease & $\begin{array}{c}\text { Nova Odessa-SP } \\
\text { DHR-VII }\end{array}$ & $\begin{array}{l}\text { Hospital for Secondary } \\
\text { Health Care ER (Nova } \\
\text { Odessa-SP) } \rightarrow \text { Hospital } \\
\text { for Secondary Health Care } \\
\text { (Nova Odessa-SP) } \rightarrow \text { Private } \\
\text { Hospital (Americana-SP) } \rightarrow \\
\text { Specialty Outpatient Clinic } \\
\text { (Americana-SP) } \rightarrow \text { Private } \\
\text { Hospital (Americana-SP) } \rightarrow \\
\text { Specialized Outpatient Care } \\
\text { at the University Hospital } \\
\text { (Campinas-SP) } \rightarrow \text { University } \\
\text { Hospital (Campinas-SP) }\end{array}$ \\
\hline
\end{tabular}

The research was conducted at the Pediatric Nursing Service of a tertiary, public, university hospital located in the interior of the State of São Paulo. Families were invited to participate in a phenomenological interview, on a previously agreed date/ time, in the child's own room or in an area outside the unit from November to December 2018, with the following guiding question: 'Tell me about the path you (and your family) traveled in search of health care for your child before arriving at this hospital'. To access the participants, the choice of convenience was used, based on the search for participants who prove to be more accessible, collaborative, and available to participate in the study (FREITAG, 2018).

The interviews were individual, digitally audio recorded, with an average duration of 17 minutes, transcribed in full for analysis of the structure of the situated phenomenon and closed when the criterion of theoretical saturation was reached, that is, when the speeches were sufficient for the researcher to unveil the phenomenon in question (RIJNSOEVER, 2017).

The research was conducted in accordance with the ethical standards required by Resolution 466/2012 of the National Health Council, and was authorized by the consubstantiated opinion number 2,813,225, of the Ethics Committee for Research with Human Beings. 
To reach an understanding of the phenomenon, the following steps were followed (MARTINS; BICUDO, 2005):

1. reading the total content of the speeches, as many times as necessary, in order to become familiar with and then grasp their global configuration;

2. attentive rereading, focusing on the guiding question, in order to identify the units of meaning, which are clippings deemed significant to the researcher. This is a movement of the human spirit that occurs through intuition, imagination, and reasoning. It is worth emphasizing that the units of meaning are not readymade in the text, but exist in relation to the phenomenological attitude/posture of the researcher. The units of meaning are then transcribed into the language of the researcher, considering the area in which the research takes place. This moment is called ideographic analysis;

3. articulation of convergences (elements that are common to several speeches) and divergences (elements that are peculiar to only one speech or a few) that resulted in the selection of meaning units originating the thematic categories. This step is also called nomothetic analysis;

4. Elaboration of a descriptive synthesis, integrating the understandings of the phenomenon in question, represented here by the therapeutic itineraries of the families of children with chronic diseases hospitalized.

\section{Results}

\section{Understanding the therapeutic itineraries of families of children with chronic diseases}

From the analysis of the speeches, several facets of the phenomenon were unveiled, emerging the following thematic categories: Walking in search of health care for their child - the beginning of the saga; Perceiving themselves as vulnerable in front of the Unified Health System; From the difficulty to get access to health to unexpected help and Arriving at the reference service - from the relief of care to the perception of the existence of new problems.

\section{Walking in search of child health care - the beginning of the saga}

The path in search of health care for the child starts from the perception of some clinical change in the child, i.e., signs and symptoms not yet presented or 
perceived as health problems. This moment happened, almost exclusively, in the home environment, from the family's daily care, especially the mother's.

And we found out that he didn't roll over in bed at seven months. Until he was seven months old he could lift his head up, move his legs, and after seven months he couldn't turn his legs or lift his head up anymore. We found out when he was seven months old and today he is four years old. (LUCK)

Only one child was diagnosed with a specific health condition in the neonatal period, right at birth.

When Lucy was born, she was born weighing 3 kilos 630, and with a cephalic pole of 32. According to the WHO, 32 is already considered microcephaly. The fact is that in the ultrasounds this PC of 32 was not diagnosed. And there was a neurological concern about it. As soon as she was discharged from the maternity ward we went to a local neurologist, and the doctor detected microcephaly, and ordered an ultrasound to confirm it. We did the ultrasound, and microcephaly was detected, but the diagnosis was not yet closed. (SAW)

Regardless of the moment of diagnosis, at birth or later, and even the age of the child, the realization that there is a health problem was the trigger for the family to seek assistance for the child.

[...]Then, with the doctor I pass in Pindamonhangaba who takes care of him, he was starting to have a high fever, he felt a lot of pain in his right leg. He did some tests and she thought it would be better if I came to this hospital, to try to get a consultation here, because he did the test and had a low platelet count, but she couldn't tell if the fever was due to the low platelet count. When I arrived here on the 13th, at 7:30 in the morning, he started to have a lot of headaches. There came a time when he couldn't stand it. The right side he was already feeling pain in his leg, he didn't feel it anymore, he didn't say a word, he was already losing his mind. (MICHAELA)

The search begins in Primary Health Care (PHC), through the Basic Health Unit, where the health team, upon realizing that it is a complex case, refers it to a specialist. However, the delay in the specialist's care, with the consequent worsening of the child's clinical condition, was determinant for the families to seek care in urgency and emergency units, since with no link to PHC, they had nowhere to turn.

On Tuesday, he had seven convulsions at home. Then we went to the hospital and stayed there for observation. (MARIA)

However, even if the child is treated in urgency and emergency services, in the municipalities of origin or in other nearby municipalities, sometimes the health problems remain unsolved because there are no specialists available. 
I think it's ugly, ridiculous. Because we have a hospital in the city that has no resources. If it is an emergency, there is no resource, the child has to leave the city to come here. But it was difficult, it is very difficult there for health. (MARIA)

Thus, the child was kept under observation for an uncertain period, but did not receive specific treatment for the health problem, but rather palliative measures such as medication for the symptoms.

And the doctors couldn't figure out what it was and would give medication just to relieve the pain. (FRANNIE)

With no answers for the child's condition, one of the families uses the global computer network, the Internet.

I saw that it had been altered. I went online and found the result and saw that it was altered. I saw many bad things about jaundice. (EMMA)

Noticing the instability of the child's clinical picture, the medical team triggers the Central Office for the Regulation of Health Service Supply (CROSS), requesting a vacancy in a reference hospital, but the transfer can take from hours to days. During this waiting period, the medical team can discuss the case with other doctors, by telephone.

As there was no neuropediatrician, the doctors in Sumare called the neuropediatrician who was treating her in Hortolândia, which is Dr. Amélia [...] And this doctor gave all the coordinates, telling which medicines for her age she could take, the doses with reference to her weight. The doctors told her how she was doing, if she was improving or not and Dr. Amélia changed the medicine, changed the dose and so on. (SARA)

While waiting for an opening, the families see themselves as vulnerable to the limitations of the Unified Health System (UHS).

\section{Perceiving themselves as vulnerable to the Unified Health System}

The children evolved in different ways, because some had to wait for a vacancy in another service due to clinical worsening; others stayed in the urgency and emergency service for a few days, but, even so, were transferred later, besides those who were discharged due to clinical improvement with a scheduled referral.

The children, with marked clinical worsening, demanded transfer to highly complex services. However, it was necessary to wait for the availability of a vacancy through CROSS, which did not occur quickly. 
Then when we went to the hospital on Tuesday, when we got there, we stayed in the emergency room all night. Early in the morning they put us in CROSS and sent us to the university hospital. (MARIA)

The children, who stayed in the urgency and emergency services, without worsening, were later transferred.

In December she was hospitalized in the city next to mine and from there they sent her here. But as it was the end of the year, it took a while for her to get here. (FRANNIE)

Children who showed clinical improvement were released from the urgency and emergency services to await appointments with specialists, but the dates for scheduling were not close, determining a wait of weeks to months.

We couldn't get the transfer here to do his treatment, we couldn't get the transfer. And we stayed there in that little life. (LUCK)

Concerned with the child's health status and the waiting time for the appointment, some professionals resorted to friendships to get to the clinic ahead of time.

So it was when the pediatrician she sees referred her here to the hospital, that he has a friend in pediatrics who treats in rheumatology. He referred her, talked directly to the doctor. So that's when he managed to get her an opening. (FRANNIE)

One of the families went to the specialized service, even though it was not the scheduled date, to request an earlier appointment, due to the worsening of the child's clinical condition.

But it took more than four months for Thomas to be called up. On Sunday he had a seizure. Then, early Monday morning, I went to the specialty clinic in town. When I got there, I asked and begged for a neurologist. They said they didn't have one, they took it and showed it to me, Thomas' name was right there at the bottom. There were several people in front. I explained the situation, I had to cry there. Then they took it and told me to come back with Thomas in the afternoon. In the afternoon we passed through. That was four months later. (MARIA)

Although most of the children got specialized care in one way or another, there were children who did not.

The vacancy at the university hospital didn't come. Then an acquaintance of ours gave us the idea of going to the public defender's office. But when we got to the public defender's office, they said that our salary, mine and my husband's, exceeded the minimum amount there to get a free lawyer. I left there VERY [emphasis added] upset, because it is a health case, so I was really upset. Because I think it has nothing to do, besides that our salary is not high [...]. So we got a lawyer, she offered to help us free of charge, making an injunction for Anna to be transferred here to the university hospital. (SARA) 
In this context of waiting, children were transferred already in critical condition, through zero vacancy.

She had a convulsion and was registered at CROSS to be sent to the university hospital. But there was no vacancy and she went to Sumaré as a zero vacancy. (SARA)

The difficulty of access was not only in relation to medium and high complexity services, but also in relation to rehabilitation services.

We went looking for physiotherapy early on. But public physiotherapy in Brazil today is very difficult, because there is usually no room, no space, no schedule, and so on... (SAW)

Facing difficulties in accessing health services, families face several dilemmas. However, unexpectedly, help comes from people they know, but also from people they don't know.

\section{From the difficulty to get access to health care to unexpected help}

Moments of difficulty were often experienced during the therapeutic itinerary, not only in accessing public health services, but also in accessing private health services.

And she already said 'I can't do anything with my hand, I can see the exams and that's it, I can't study, I can't analyze. I can only see the exams and conclude something with those exams in my hand. So I get very stuck" she said. Health Insurance doctors are very stuck, they are very restrictive. (CHRISTY)

The lack of family support also emerged as a difficulty, including family conflict due to disagreement between the family about the child's real need to be treated in a referral hospital.

My husband, in the beginning, when he was 3 years old, he thought it was silly. $\mathrm{He}$ wanted to go to Pindamonhangaba instead of coming here. Then I told him: 'Look, from everything that the doctors said, I think that Pindamonhangaba is the ideal place. At first he didn't accept it, so much so that in the beginning I even separated him. I spent some months separated from him, because he didn't accept it. (MICHAELA)

In this context, families report feelings, generally negative, about the child's health problem before the discovery of the diagnosis, and the wait for a vacancy in the reference hospital also contributed to reinforce these feelings. However, it was in these moments that the families found support, either from other family members or close friends.

I won't say it was an easy path, you know? But so, another thing that also depends a lot on us to get somewhere right is family. I think that if it wasn't for her father, my husband, if it wasn't for him, we wouldn't have been able to do her surgery [cries emotionally]. (KATE) 
Moreover, besides the support of family and close friends, there were participants who received unexpected help from unknown people, which positively influenced the therapeutic itinerary.

We discovered [the disease] because we did a private examination. The exam cost $\mathrm{R} \$ 10,000$ reais, the population helped. The population, the church with bingo, with a CHURCH PARTY [emphasis added]. The people on the street buying raffle tickets and we managed to get the money together, that's when we were able to do his genetic test. (LUCK)

So we got a lawyer, she offered to help us free of charge by making an injunction for Anna to be transferred here to the university hospital (SARA).

After facing several difficulties and receiving unexpected help, the long-awaited moment occurs when the child finally arrives at the reference hospital in search of diagnosis and treatment. Thus, these families experience a sense of relief because, initially, they believed that the health service would be able to fully solve the children's problems. However, they are faced with the existence of new problems that they did not expect.

\section{Arriving at the referral service - from the relief of care to the perception of the existence of new problems}

Upon arrival at the reference hospital, the child is hospitalized, and soon afterwards, a diagnostic investigation is initiated through a series of tests, both laboratory and imaging, and not uncommonly, tests that require surgical procedures.

At the first moment, Dr. Débora, the pediatrician, requested the bilirubin and liver function tests. Both were already altered and she referred us to the gastro, to Dr. Guilherme, to be doing an ultrasound on Tuesday and to see him. [...] And he requested a liver biopsy. [...] We had the partial result on Wednesday that would be an atresia, and that there was no cirrhosis or fibrosis, for now only an atresia. (EMMA)

During the diagnostic investigation, the family believes in the possibility of finding treatment and cure for their child's disease, regardless of the child's clinical picture. Thus, hope emerges as a coping strategy for the new reality.

Now they have told me that we will be treated for the rest of our lives with Pepper, that the surgery is not a curative surgery, that even though the surgery was a success, when they opened it, they didn't see any signs of cirrhosis or fibrosis, there weren't many lesions in the liver. But we believe, we trust and we will follow up here with Pepper. And we trust that he will not need to undergo transplantation. (EMMA) 
After the confirmation of the diagnosis is the moment to start the treatment in the reference hospital, which comforts the family, once they believe that in the high complexity service they have the adequate support to perform the necessary.

The gastro, here at the university hospital, detected, they did MANY [emphasis added] exams, they detected that she had a very serious reflux problem and that her problem was a surgical case. This was in March and Dr. Guilherme TO [emphasis added] not let Lucy malnourished, thought it best to pass a nasogastric tube until [emphasis added] the issue of Lucy's surgery was solved. (SAW)

Furthermore, the family attributes to divine power the possibility of treatment and healing for their son.

It was God himself who sent him, because if it wasn't for him I wouldn't be with my boy here, treating him [laughs]. I just have to say thank you, may God continue to bless this place, the doctors, the nurses, may God bless each one. (MICHAELA)

Aware of the diagnosis and the proposed treatment, the family evaluates positively both the health team and the reference hospital, showing safety and confidence, even highlighting that without these resources; they would not be able to make the child's treatment possible.

I think that this is a little piece of heaven, because I can't imagine his life without this place. [I can't imagine life without them here. [...] But so, we just have to thank this whole team that has assisted us until today, since the beginning three years ago and until today, that accompanies us. [...] I just have to thank them for the fact that this place exists, for having good people until now. (MICHAELA)

However, not all families felt safe with the care they received. Some negatively evaluated the service and the team in general, reporting disrespect from health professionals when questioned about the treatment.

Because I think like this: if I am here I have to respect the professionals that are working, but the professionals that are working also have to respect me, with my life and with my son. If I don't feel satisfied here, I think I will have to look for another one. The reality is that it is a university that is also maintained with my tax money. Everything I pay in taxes is being contributed here. (ISABEL)

Faced with dissatisfaction, families reflect on their role as citizens and how they want the health service, financed by society's funds, to welcome them - with respect and competence. 


\section{Discussion}

Brazilian law number 8.080/90 established the Unified Health System (UHS), which ensures that health is a right of all and a duty of the State. Thus, the State must ensure universal, integral, and equal access to health actions and services in order to promote, protect, and recover health (BRASIL, 1990).

Through the UHS, the population must have access to health services articulated in increasing levels of complexity in order to achieve comprehensive care. Thus, the entrance door is Primary Health Care (PHC), through the Family Health Strategy (FHS), which has the centrality in the family, the link with the user, completeness, and coordination of care, articulation with the care network, social participation, and intersectoral action as guiding principles (ARANTES; SHIMIZU; MERCHÁNHAMMAN, 2016).

Thus, it is from PHC that the referral to medium and high complexity services must occur, since it is this level of care that is responsible for organizing users' access to services, identifying health demands, as well as paying attention to the need for referral to other services (PEITER; LANZONI; OLIVEIRA, 2016) after exhausting all possibilities for care, making use of the pillars of universality, accessibility, equity, accountability, and humanization (BRASIL, 2012).

Thus, PHC assumes the coordination of the Health Care Networks (HCN) in order to ensure continuity of care, in an integrated manner among the other levels of the system, also considering the process of territorialization, which goes beyond the delimitation of the territory, but includes bonding and belonging of the population with the services. Therefore, the HCN and territorialization are strategies for planning, organizing and restructuring the health system, with positive impact on community health (RODRIGUES et al., 2014; FERNANDES et al., 2017).

However, the supply of health care did not follow population growth, nor the change in the health-disease profile of the population, from acute to chronic noncommunicable diseases (CNCDs), which generated the need for medium and high complexity care (GAWRYSZEWSKI; OLIVEIRA; GOMES, 2012), in a context of decentralization and regionalization of health, prior to the UHS.

Health decentralization/regionalization is a process of political, administrative, and financial power transfer from the federal government to the state and municipal governments, with shared responsibility among the management spheres, which 
results in interdependence among the entities. Although it began before 1990, it was in 2000 that it received emphasis in the national plan (PEREIRA; LIMA; MACHADO, 2018).

Despite this, it is still a great challenge for municipal management, which cannot guarantee users access to medium and high complexity services due to flaws in the territorialization process and to the ineffective functioning of the HCN because of lack of support from the state, which weakens municipal services and the relationship between health workers and users (SILVA; BENITO, 2013).

The children of the participants in this study who were being monitored for childcare in the PHC or had a pediatrician as a reference in the health insurance network, were referred to specialists in secondary and tertiary services, because these services are responsible for planning and carrying out medium and high complexity actions, not available in the PHC (AGUILERA, 2014).

However, with regard to the public network, scheduling can be very slow, such as in the municipality of Rio de Janeiro, where the wait for an appointment with a specialist takes approximately 80 days (PINTO et al., 2017), which leaves the child without care, at risk of worsening the clinical picture. In view of this, the family seeks urgency and emergency services.

Families of children living in a city in the state of Paraná reported organizational barriers imposed by the PHC health team, which were related to the lack of welcoming and the precariousness in the understanding of the health-disease process and, for this reason, chose to seek health care in urgency and emergency services, overloading these services and affecting the quality of care provided (SILVA; VIEIRA, 2014).

In order to improve the communication between PHC and the medium and high complexity service network, as well as to optimize the demand for services with the available resources, the Health Service Offering Regulation Center (CROSS) was created, which works 24 hours a day, regulating beds in public hospitals, so as to ensure adequate assistance for the demands presented by the patients (FERRAZ; CARREIRO, 2018).

In the urgency and emergency services of small municipalities, the medical team, due to the clinical worsening of the child, needed to transfer him to more complex services in other municipalities, through the CROSS. However, the transfer took from hours to days. 
During this wait, some children evolved with clinical improvement and were discharged with referral to a specialty. However, due to the long waiting period, there were doctors who, due to friendships, were able to anticipate the service, and there were also families who sought services after the scheduled date or through judicial appeals.

Judicial action is used as a way to guarantee universal and full access to health care, as established by the Federal Constitution. However, when using this tool, equity is harmed, since one of the criteria for bed regulation is the patient's clinical status. Those who use the legal action have priority in care, causing disorganization in the waiting line. Moreover, not all the population has access to legal resources, while to use this tool, in many cases, people have higher economic and educational level (PEITER; LANZONI; OLIVEIRA, 2016; FERRAZ; CARREIRO, 2018).

Other children worsened significantly, and were transferred through the Zero Vacancy resource. Ordinance MS/GM No. 2048/02 established the concept of Zero Vacancy. It is the obligation of the services to receive patients, even without conditions to do so, because there is no other door available for referral (BRASIL, 2002). However, until the transfer is effective, the child's condition deteriorates, which may decrease the chances of recovery.

It is worth noting that the difficulty of access was not only for medium and high complexity hospital services, but also for rehabilitation services. The city of Curitiba had, until 2012, huge waiting lines for non-medical care. This situation was addressed through the implementation of the Family Health Support Center (FHSC), which used the matriciamento to improve the resoluteness of care (TESSER; POLI NETO, 2017).

The long wait for specialized care and/or the worsening of the child's clinical condition led families to seek care in health services provided by health insurance companies or private companies, believing that the care would be faster when compared to the public health services.

But they encountered other difficulties, such as complementary services that were not available and, also, the cost beyond the family's means. Regardless of the sector where the care will take place, the diagnosis and treatment are not made quickly and, in some cases, referral to other services is necessary (GIRARDONPERLINI et al., 2018). 
For the participants of this study, the performance of complementary exams and the confirmation of the diagnosis occurred in highly complex services of the public sector, i.e., in the reference hospital. Therefore, there are situations in which treatment occurs almost exclusively through the UHS, as in the case of chronic kidney disease. The UHS is responsible for $90 \%$ of the treatments that include dialysis and transplantation (ALCALDE; KIRSZTAJN, 2018).

To meet the child's needs, the family can sometimes come into conflict. Mothers of children with autistic disorder report family conflict, lack of support, especially from the spouse with impact on the marital relationship (ZANATTA et al., 2014), corroborating the results of this study.

Family support is essential when facing difficult situations, as in the case of illness. In the therapeutic itinerary of individuals with head and neck cancer, they emphasized that the family plays an important role in making decisions about the health of the patient, as well as helping in the therapeutic flow by encouraging choices (GIRARDON-PERLINI et al., 2018).

Families of people with rare diseases revealed that support, both from friends and strangers, contributes to overcoming the difficulties experienced (LUZ; SILVA; DEMONTIGNY, 2016), likewise, in this study, families who received some kind of support were grateful and strengthened to continue the path in search of their child's health.

It is important to emphasize that, although the families have started the therapeutic itinerary in PHC, soon after the onset of the first signs/symptoms, the diagnosis and the beginning of treatment took place in public services of tertiary level, even for those who opted for private and health insurance services (LIMA et al., 2018).

Once diagnosed, the child starts treatment. Although it is sometimes palliative, the family demonstrates hope, through divine faith, for a cure. Thus, they experience a sense of relief by finally seeing their child protected. Moreover, the confidence in the health team and the health service collaborate to maintain optimism (SILVA et al., 2017). But, although hopeful of finding definitive solutions for their children's health problems, families point out mishaps in interpersonal relations with the health team.

Families considered difficult to contact may keep health professionals away, making it impossible to identify the emotional and psychosocial demands, which 
makes hospitalization an even more painful process (AZEVÊDO; LANÇONIJÚNIOR; CREPALDI, 2017). It is necessary to reflect on the overload that the family goes through when facing the hospitalization of their children, trying to meet their needs.

For this, communication is an indispensable resource in establishing the relationship between the family and the health team. Efficient and appropriate communication is essential when adopting child and family centered care, because this philosophy of care emphasizes the importance of respecting and valuing the family's discourse, in order to build a relationship based on trust and affection (MENEZES; MORÉ; BARROS, 2016).

\section{Final considerations}

This study sought to understand the therapeutic itineraries of families of children with chronic diseases. Children with chronic diseases and their families experience a long process of seeking access to health care, mainly due to the need for referral to specialties and referral hospitals, which have spatial, material, and human resource limits, among others.

The referral of children varied according to their clinical condition and the possibilities of the service, and there were children who were transferred through a zero vacancy, already in critical condition. Others arrived at the reference hospital days after the request for a vacancy, which caused anguish in the families because they felt helpless before the children's needs. Relief and hope emerged only after the transfer, which was pointed out by all the families.

Although the families received the diagnosis and the indication of treatment for the children, during this process there were marital conflicts and lack of support from other family members, reported by some participants. Others received help and expressed gratitude. In this context, the families experienced another difficulty - the news that their children's diseases would need treatment for life, which was apprehended with divine hope, but the relationships with the health team were perceived as hindering this moment.

With regard to the dialogue between the services of the various managerial spheres, communication failures cause delays in care and, consequently, can cause harm to the child. Furthermore, the municipalities need to know the real health 
needs of the population in order to plan health actions, that is, to carry out the process of territorialization.

This research was limited to studying the TI of families of children with chronic diseases hospitalized, with the participants residing at a maximum distance of 312 $\mathrm{km}$, but questions are being asked about families and children who, perhaps, could not get referrals to the reference hospitals, considering the increase in the number of cases of children with chronic non-communicable diseases.

Thus, it is necessary commitment and responsibility to manage and invest the public financial subsidies. One must also think about the importance of the role of the health professionals who receive these families and children, to be supportive in these moments of difficulty, providing what is necessary for them to feel welcome and receive all the indispensable information to participate in the decision of caring for their children.

\section{References}

AGUILERA, S. L. V. U. et al. Intermunicipal inequities in access and use of secondary health services in the metropolitan area of Curitiba. Revista Brasileira de Epidemiologia, Sáo Paulo, v. 17, n. 3, p. 654-667, 2014.

ALCALDE, P. R.; KIRSZTAJN, G. M. Expenses of the Brazilian Public Healthcare System with chronic kidney disease. Brazilian Journal of Nephrology, São Paulo, v. 40, n. 2, p. $122-$ 129, 2018.

ALVES, P. C. Itinerário terapêutico e os nexus de significados da doença. Política \& Trabalho: Revista de Ciências Sociais, Alagoas, n. 42, p. 29-43, 2015.

ARANTES, L. J.; SHIMIZU, H. E.; MERCHÁN-HAMMAN, E. The benefits and challenges of the Family Health Strategy in Brazilian Primary Health care: a literature review. Ciência \& Saúde Coletiva, Rio de Janeiro, v.21, n. 5, p. 1499-1509, 2016.

AZEVÊDO, A. V. S.; LANÇONI-JÚNIOR, A. C.; CREPALDI, M. A. Nursing team, family and hospitalized child interaction: an integrative review. Ciência \& Saúde Coletiva, Rio de Janeiro, v. 22, n. 11, p. 3653-3666, 2017.

BADINTER, E. Um amor conquistado: o mito do amor materno. Tradução: Waltensir Dutra. Rio de Janeiro: Nova Fronteira, 1985.

BICUDO, M. A. V. (Org.) Pesquisa qualitativa segundo a visão fenomenológica. São Paulo: Cortez, 2011. 
BRASIL. Lei no 8.080, de 19 de setembro de 1990. Dispóe sobre as condições para a promoção, proteção e recuperação da saúde, a organização e o funcionamento dos serviços correspondentes e dá outras providencias. Diário Oficial da União, Brasília, DF, 20 set 1990. Seção 1, p. 018055. BRASIL. Ministério da Saúde. Portaria no 2048, de 5 de novembro de 2002. Aprova o Regulamento Técnico dos Sistemas Estaduais de Urgência e Emergência. Diário Oficial da União, Brasília, DF, 12 nov. 2002. Seção 1, p. 32-54.

BRASIL. Ministério da Saúde. Secretaria de Atenção à Saúde. Departamento de Atenção Básica. Politica Nacional de Atenção Básica. Brasília, DF, 2012.

BRASIL. Ministério da Saúde. Secretaria de Atenção Básica à Saúde. Departamento de Atenção Básica. Diretrizes para o cuidado das pessoas com doenças crônicas nas redes de atenção à saúde e nas linhas de cuidados prioritárias. Brasília, DF, 2013

CHELO, D. et al. Verbal autopsy and therapeutic itinerary of children who die before arrival in a paediatric centre in Yaoundé, Cameroon. Translational Pedriatrics, Shatin, v. 5, n. 1, p. 16-22, 2016.

COLESANTE, M. F. L. et al. Impacto na vida de mães cuidadoras de crianças com doença crônica. Revista de Enfermagem da UERJ, Rio de Janeiro, v. 23, n. 4, p. 501-506, 2015.

FERNANDES, L. T. B. et al. Supported self-care for children and adolescents with chronic disease and their families. Revista Brasileira de Enfermagem, Brasília, DF, v. 70, n. 6, p. 13181329, 2017.

FERNANDES, V. R. et al. O lugar da vigilância no SUS - entre os saberes e as práticas de mobilização social. Ciência \& Saúde Coletiva, Rio de Janeiro, v. 22, n. 10, p. 3173-3181, 2017.

FERRAZ, A. R.; CARREIRO, M. A. Reflexão teórica sobre a regulação de leitos de terapia intensiva em um município do Rio de Janeiro. Revista Pró-Universus, Vassouras, v. 9, n. 1, p. 76-80, 2018.

FREITAG, R. M. K. Amostras sociolinguísticas: probabilísticas ou por conveniência? Revista de Estudos da Lingua(gem), Belo Horizonte, v. 26, n. 2, p. 667-686, 2018.

GAWRYSZEWSKI, A. R. B.; OLIVEIRA, D. C.; GOMES, A. M. T. Acesso ao SUS: representaçôes e práticas de profissionais desenvolvidas nas Centrais de Regulação. Physis: Revista de Saúde Coletiva, Rio de Janeiro, v. 22, n. 1, p. 119-140, 2012.

GIRARDON-PERLINI, N. M. O. et al. "The back and forth of consultations": therapeutic itinerary of people bearing head and neck cancer. Revista Cuidado é Fundamental, Rio de Janeiro, v. 10, n. 4, p. 1032-1040, 2018.

LIMA, B. C. et al. The therapeutic pathway of families of children with cancer: difficulties faced in this journey. Revista Gaúcha de Enfermagem, Porto Alegre, v. 39, p. e20180004, 2018. 
LUZ, G. S.; SILVA, M. R. S.; DEMONTIGNY, F. Priority needs referred by families of rare disease patients. Texto \& Contexto - Enfermagem, Florianópolis, v. 25, n. 4, p. 1-9, 2016.

MARTINS, J.; BICUDO, M. A. V. A pesquisa qualitativa em psicologia: fundamentos e recursos básicos. São Paulo: Moraes, 2005.

MARTINS, L.C. et al. Itinerário terapêutico de crianças quilombolas com doença falciforme. Ciência, cuidado e saúde, Maringá, v.18, n. 2, p.1-8, 2019.

MENEZES, M.; MORÉ, C. L. O. O.; BARROS, L. Social networking family of caregivers during hospitalization of children. Revista da Escola de Enfermagem da USP, São Paulo, v. 50, p. 107-113, 2016. Número especial.

MOURA, E. C. et al. Complex chronic conditions in children and adolescents: hospitalizations in Brazil, 2013. Ciência \& Saúde Coletiva, Rio de Janeiro, v. 22, n. 8, p. 2727-2734, 2017.

NDIAYE, M.; SARLI, L. Recourse to multiple treatments or the problem of the therapeutic itinerary in Louga. Acta Bio-Medica dell'Ateneo parmense, Parma, v. 85, n. 3, p. 74-80, 2014.

PEITER, C. C.; LANZONI, G. M. M.; OLIVEIRA, W. F. Healthcare regulation and equity promotion: the National Regulation System and the health access in a large municipality. Saude em Debate, Rio de Janeiro, v. 40, n. 111, p. 63-73, 2016.

PEREIRA, A. M. M.; LIMA, L. D.; MACHADO, C. V. Decentralization and regionalization of health policy: a historical-comparative approach between Brazil and Spain. Ciência \& Saúde Coletiva, Rio de Janeiro, v. 23, n. 7, p. 2239-2251, 2018.

PEREIRA, O. S. Fenomenologia da prática: investigação em enfermagem da experiência vivida. Revista de Enfermagem da UFPE On Line, Recife, v. 9, n. 10, p. 9608-9615, 2015.

PINTO, L. F. et al. Ambulatory municipal regulation of the Unified Health System services in Rio de Janeiro: advances, limitations and challenges. Ciência \& Saúde Coletiva, Rio de Janeiro, v. 22, n. 4, p. 1257-1267, 2017.

RABELO, M. C. M.; ALVES, P. C. B.; SOUZA, I. M. A. Experiência de doença e narrativa. Rio de Janeiro: Fiocruz, 1999.

RIJNSOEVER FJ van. I can't get no saturation: a simulation and guidelines for sample sizes in qualitative research. PLoS ONE, San Francisco, v. 12, n. 7, p. e0181689, 2017.

RODRIGUES, L. B. B. et al. Primary Health Care in the coordination of health care networks: an integrative review. Ciência \& Saúde Coletiva, Rio de Janeiro, v. 19, n. 2, p. 343-352, 2014.

SALVADOR, M. S. et al. Strategies of families in the care of children with chronic diseases. Texto \& Contexto - Enfermagem, Florianópolis, v. 24, n. 3, p. 662-669, 2015.

SILVA, B. F. S.; BENITO, G. A. V. The voice of municipal administrators on access to health in management practices. Ciência \& Saúde Coletiva, Rio de Janeiro, v. 18, n. 8, p. 2189-2220, 2013. 
SILVA, D. B. et al. Experiences and feelings of mothers of children with Moyamoya disease. Estudos de Psicologia, Campinas, v. 34, n. 4, p. 523-533, 2017.

SILVA, R. M. M.; VIEIRA, C. S. Access to child's health care in primary care services. Revista Brasileira de Enfermagem, Brasília, DF, v. 67, n. 5, p. 794-802, 2014.

SIQUEIRA, S. M. C.; JESUS, V. S.; CAMARGO, C. L. The therapeutic itinerary in urgent/ emergency pediatric situations in a maroon community. Ciência \& Saúde Coletiva, Rio de Janeiro, v. 21, n. 1, p. 179-189, 2016.

TESSER, C. D.; POLI NETO, P. Specialized outpatient care in the Unified Health System: how to fill a void. Ciência PLoS ONE Saúde Coletiva, Rio de Janeiro, v. 22, n. 3, p. 941-951, 2017.

ZANATTA, E. A. et al. Families that live with child autism on a daily basis. Revista Baiana de Enfermagem, Salvador, v. 23, n. 2, p. 208-221, 2014. 


\section{Resumo}

\section{Itinerário terapêutico de famílias de crianças com doenças crônicas}

Objetivo: compreender os itinerários terapêuticos de famílias de crianças com doenças crônicas. Método: estudo fenomenológico realizada em hospital universitário, com 10 famílias de crianças com doenças crônicas que participaram de entrevista fenomenológica com a questáo norteadora - 'Conte-me a respeito do caminho que você (e sua família) percorreu em busca de atendimento de saúde para o seu filho antes de chegar nesse hospital'. Resultados: emergiram quatro categorias temáticas: Caminhando em busca de assistência à saúde do filho - o início da saga; Percebendo-se vulneráveis diante do Sistema Único de Saúde; Da dificuldade para conseguir acesso à saúde à ajuda inesperada e Chegando ao serviço de referência - do alívio do atendimento à percepção da existência de novos problemas. Discussão: algumas famílias foram encaminhadas por vínculo de amizade, transferência por meio de vaga zero e demanda espontânea em outros serviços de saúde. Após o diagnóstico e início do tratamento, a família demonstrou esperança de cura, relatando sensação de alívio ao perceber a criança sendo assistida. Conclusão: Evidenciou-se que as crianças com doenças crônicas e seus familiares vivenciam um longo processo de busca de acesso à saúde, principalmente devido à necessidade de encaminhamento para hospitais de referência.

Palavras-chave: família; acesso aos serviços de saúde; enfermagem pediátrica. 